\title{
DYNAMIC OF FUNCTIONAL INDICATORS' CHANGES OF STUDENTS HAVING HARMFUL HABITS (ON EXAMPLE OF SMOKING) UNDER INFLUENCE OF ORGANIZED MOTION FUNCTIONING
}

Pidpomoga A.Y.

\author{
National University of Physical Education and Sport of Ukraine
}

\begin{abstract}
Purpose: determination of organized motion functioning on functional indicators and somatic health of $1^{\text {st }}-2^{\text {nd }}$ year students, who have harmful habits. Material: In experiment 286 students participated. Pedagogic experiment was conducted in form of optional classes (3 times a week) during 9 academic months. Results: we determined percentage of smoking students and their motivation to certain kinds of sports. Considering students' motivation appropriate trainings were organized. Results of functional state indicators and somatic health level of smoking students, practicing and not practicing organized motion functioning have been presented. Conclusions: it was found that students are attracted by specific kinds of motor functioning. Among offered kinds of sports outdoor games, athletic gymnastic were preferred. The least attractive kinds were: bicycle sport, non- traditional kinds, gymnastic, chess.
\end{abstract}

Key words: addictive behavior, harmful habits, motor functioning, students.

\section{Introduction}

The problem of health worsening in Ukraine acquires character of demographic disaster, which already has reached to conception "degeneration of nation" [7, 20]. The data of world statistics confirm that Ukraine takes leading place in Europe by mortality and one of the last places in the world by lifespan [19, 20]. Researches show that not more than $10 \%$ of Ukrainian youth can be regarded as practically healthy. The rest have different deviations in health. As per statistical data more than $65 \%$ of HEE students have insufficient physical fitness $[2,7,11]$. As on to day, in conditions of military mobilization it has been noted that more than $60 \%$ of youth are not suitable for military service [20]. With every year, quantity of workable youth with expressed signs of addictive behavior - harmful habits: tobacco, alcohol, drugs addictions - increases. Also there is a trend to increasing of mental disorders among youth and insufficient health $[4-6,10]$. It is conditioned by rapid expansion of not infectious diseases (for example, cardio-vascular diseases in 62\% are main reasons of mortality). Besides there is epidemic of obesity, hyper-tension, diabetes and so on (see fig.1). Thus, health of Ukrainian citizens is the problem of national security of the state $[6,9,15,19]$. It is evident that the most effective mechanism of morbidity and mortality among workable strata of population indicators' reduction is formation of healthy life style. It includes adequate organized motor functioning in natural combination with rational eating, giving up harmful habits, prophylaxis of stresses' after effects and improvement of ecology $[8,10,14,18]$.

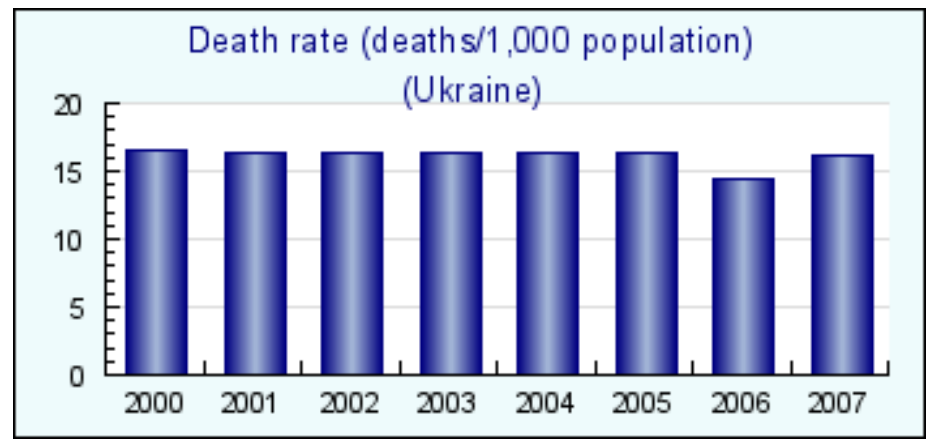

Fig.1. Mortality (deaths/100 of people) in Ukraine [http://chinalist.ru/facts/viewyears.php?p_lang=1\&p_param=20\&p_country=223].

One of serious problems of Ukrainian society - is critical level of harmful habits (especially among youth). It is known that smoking is the most mass harmful habit in the world. It damages health of separate person and society in general $[1,3,12]$. Results of the researches, conducted by N.Yu. Maksimova, O.I. Bondarchuk and I.M. Bogdanova, prove significance of this problem for modern Ukrainian society. As on to day in students' environment there exists clear trend to expansion of harmful habits: smoking, taking alcohol, drugs and toxic substances. It results in worsening of students' health $[5,6,8,13]$.

Nowadays, world practice has accumulated rather great experience in application of programs on social prophylaxis of harmful habits for different strata of population. But there is no clear conception in our country. That is why there is acute demand in preventive health related programs and pedagogic technologies of harmful habits' prophylaxis as well as application of them in conditions of higher educational establishments. By the present time the problem of application of smoking preventive measures among students with the help of specially organized motor functioning in conditions of higher educational establishment has not been studied yet [10, 14, 16-18]. In this connection the offered subject of the research is rather urgent. 
One of latent indicators of personality's slow ruining and society's degradation is expansion of harmful habits among population (especially among youth as creative potential of the society). To day the trends of tobacco, alcohol and drug addictions acquire epidemic scale, which takes thousands of lives.

Unfortunately, as on to day "model of fashionable and high-style life" is connected for many young people exactly with harmful habits. This situation is still heavier, owing to existing in Ukraine easy access to tobacco and alcohol articles, with commercial character of media means. It hampers propaganda of healthy life style and values, connected with health. It also forms low level of understanding of harmful after effects' danger for person and society [16-18].

In this connection it is necessary to seek for the most effective ways of harmful habits' correction and prophylaxis. One of them can be involvement of youth in systemic training to organized motor functioning.

Purpose, tasks of the work, material and methods

The purpose of the work is to determine influence of organized motor functioning on students' functional indicators and physical health (meaning $1^{\text {st }}$ and $2^{\text {nd }}$ year students, who have harmful habits - on example of smoking). The methods of the research: theoretical analysis and generalization of scientific literature data, sociological methods (questioning, oral questioning); pedagogic methods (pedagogic observation and experiment); physiological methods of research; express-assessment of somatic health (by G.L. Apanasenko's methodic); methods of mathematical statistic.

Organization of the research: $2861^{\text {st }}$ and $2^{\text {nd }}$ year students of Kiev university of management and enterprising participated in pedagogic experiment. For solution of our tasks the researches were conducted in three stages (from September 2014 to May 2015). Experimental and control groups (each $-\mathrm{n}=38$ ) were formed.

\section{Results of the research}

Results of pedagogic observation and questioning witness that $1^{\text {st }}$ and $2^{\text {nd }}$ year students are attracted by certain kinds of motor functioning (see fig.2).

Non- traditional kinds of sports

Chess, checkers

Bicycle sport

Swimming

Dances

Tourism and orientation

Track and field events

Extreme kinds of sports

Athletic gymnastic

Martial arts

Gymnastic, acrobatic

Outdoor games
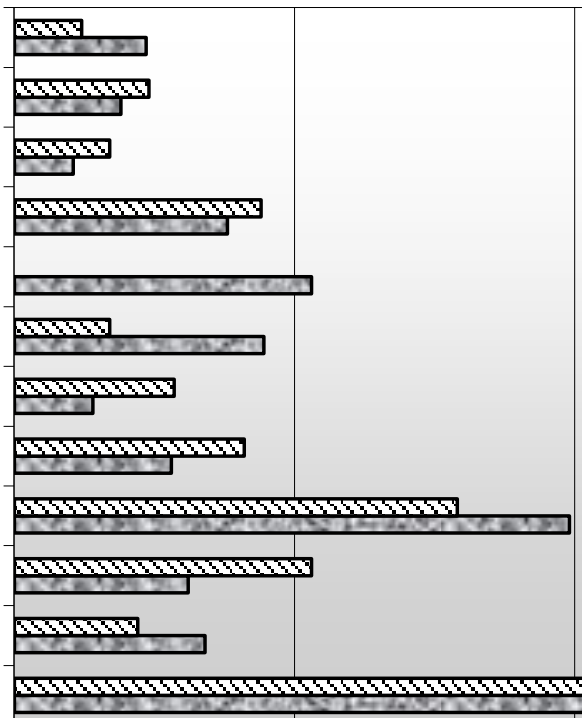

0

10

20

Quantity of students, \%

Fig.2. Distribution of boys and girls, depending on the chosen kind of motor functioning $(n=286)$ :

N - boys; $\mathrm{Q}$ - girls.

Among the offered kinds of sports smoking students preferred: outdoor games (boys - 36.8\%; girls - 28,7\%); athletic gymnastic (boys- 19.8\%; girls - 15.6\%); dances (popular only among girls- 10.6\%); health related swimming (boys- $7.6 \%$; girls $-8.8 \%$ ). The kinds of sports, preferable by students least of all, turned out to be the following: bicycle sport (boys $-3.4 \%$; girls $-2.1 \%$ ); gymnastic and acrobatic as well as non traditional kinds of sports (u-shu, tsigun, chess and checkers). That is why, considering students' motivation to preferred by them kinds of sports we organized appropriate trainings.

Formative pedagogic experiment was conducted in the form of optional classes (three times a week) during 9 academic months by group or individual method. Each training lasted one and half hour. For correction of functional state and physical condition indicators of students we offered the following means of motor functioning (see fig.3):

- outdoor games (football, volleyball, basketball) - for training of required motor qualities (quickness, endurance, coordination); technical arsenal of motor skills; rising of psycho-emotional potential;

- athletic gymnastic (exercises of power orientation, exercises on simulators) - for correction and perfection of power qualities and insufficiently developed sides of sensor and muscular systems (see fig. 4). 


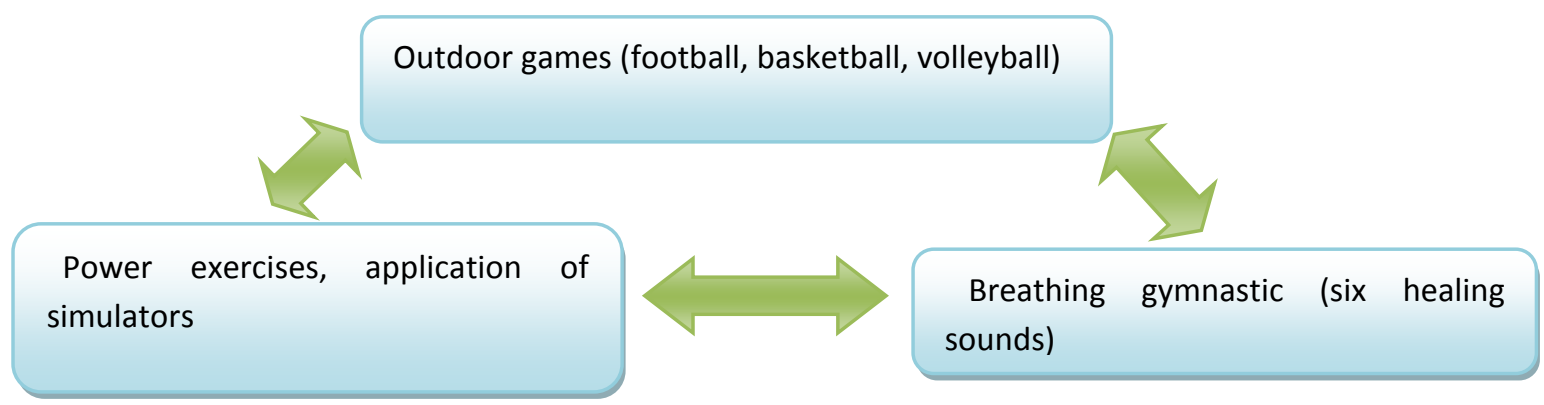

Fig.3. Complex of specially organized motor functioning's means, which were used in pedagogic experiment

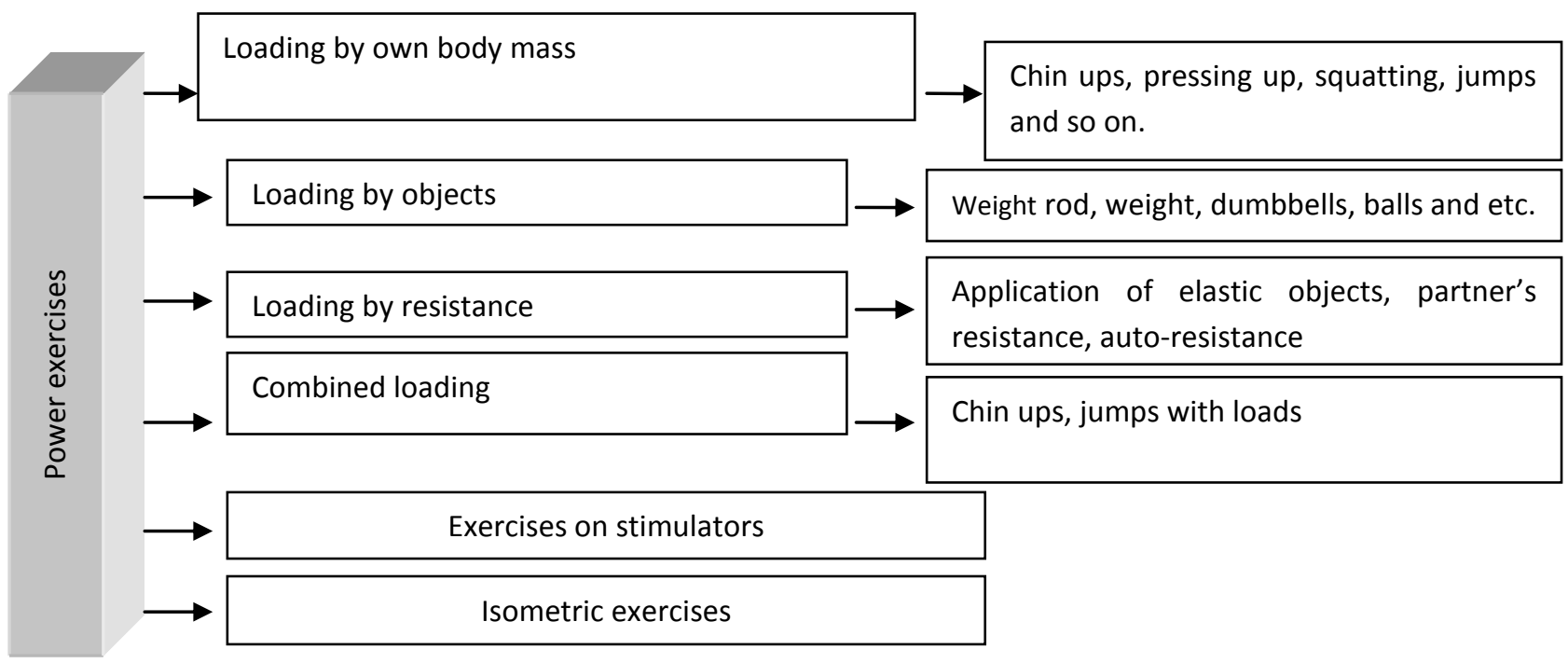

Fig.4. Complex of means for training of students' strength, which were applied in pedagogic experiment.

We also applied Chinese breathing gymnastic "Six healing sounds". It renders positive influence on cardiovascular system (improves blood circulation), respiratory system (increase gas metabolism and drainage of lungs), digestive (improves intestinal peristalsis and functioning of liver) and nervous system (relaxation, stimulation of will and creative processes, improvement of blood circulation in brain). This gymnastic also facilitates recreation of organism during and after physical loads.

$\mathrm{Al}$ above mentioned forms of trainings were used complexly in pedagogic experiment. It corresponded to our purpose and tasks of the research. For each from the offered forms of trainings certain time (in percentage) was assigned. It was motivationally justified from the point of questionings and talks, conducted by us. For example outdoor games took $55 \%$, athletic gymnastic and power exercises $-35 \%$, Chinese breathing exercises $-10 \%$ from total time.

Discussion

Analysis of scientific literature (M.M. Bulatova, 2004; V.I. Zemtsova, 2006; I.S. Korolchuk et al.,1998; L. Dvoretskaya, 2012) showed that one of serious problems of modern society is critical level of harmful habits' expansion among youth. As on to-day in students' environment there exists clear trend to addictive behavior. It results in "critical" level of students' health.

A number of researches (A.Yu. Pidpomoga et al., 2011, 2014; V.G. Griban, 2011; M.M. Bulatova, 2004) showed significant progress in application of different kinds of motor functioning for prophylaxis of harmful habits among youth. However, general conception has not been worked out in our country.

Results of our research permit for us to state unsatisfactory functional condition of $1^{\text {st }}-2^{\text {nd }}$ year students, who have harmful habits (see table 1 and fig. 5). It is also proved by the data of scientific literature: T.I. Andreyeva, 2004; O. Bondarchuk, 2006; N.A. Zalygina et al., 2004; V.I. Zemtsova, 2006; I.S. Korolchuk et al., 1998. 
Table 1

Characteristics of functional indicators of main group students before and after pedagogic experiment, $\%(n=19)$

\begin{tabular}{|c|c|c|c|c|c|}
\hline \multirow{3}{*}{ Results } & \multicolumn{5}{|c|}{ Description of indicator } \\
\hline & VCL, ml & $\begin{array}{c}\text { Dynamic } \\
\text { spirometry, } \\
\text { ml }\end{array}$ & $\begin{array}{c}\text { Shtange's } \\
\text { test, sec. }\end{array}$ & $\begin{array}{l}\text { Genchi's } \\
\text { test, sec. }\end{array}$ & $\begin{array}{l}\text { Index of } \\
\text { will, \% }\end{array}$ \\
\hline & \multicolumn{5}{|c|}{ Quantity of students, \% } \\
\hline \multicolumn{6}{|c|}{ Before experiment } \\
\hline Excellent & - & - & - & - & - \\
\hline Satisfactory & 57.8 & 47.4 & 36.8 & 42.2 & 36.8 \\
\hline Unsatisfactory & 42.2 & 52.6 & 63.2 & 57.8 & 63.2 \\
\hline \multicolumn{6}{|c|}{ After experiment } \\
\hline Excellent & - & - & - & - & - \\
\hline Satisfactory & 73.6 & 68.4 & 78.9 & 84.2 & 78.9 \\
\hline Unsatisfactory & 26.4 & 31.6 & 21.1 & 15.8 & 21.1 \\
\hline
\end{tabular}

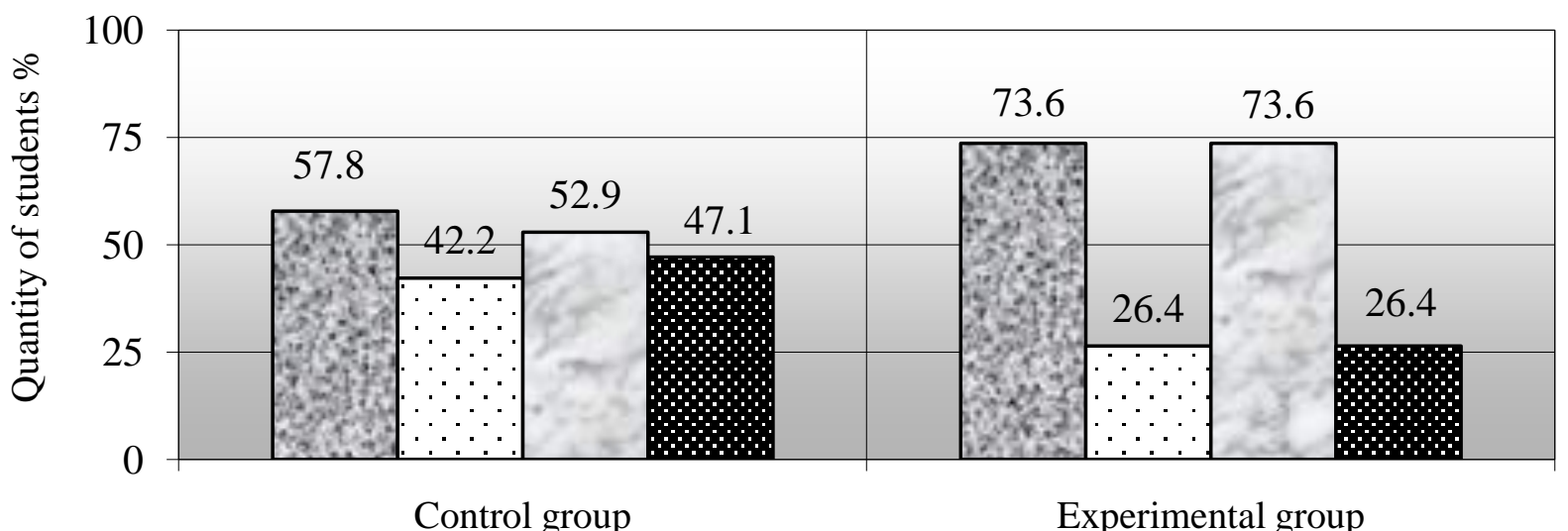

Fig.5. Distribution of control and experimental groups' students in compliance with indicators of heart beats rate $(H B R)$ and blood pressure $(B P)(n=38)$ :

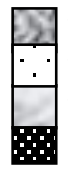

- HBR is within physiological standards;

- HBR exceed physiological standards;

- BP - is within physiological standards;

- BP exceeds physiological standards;

VCL - vital capacity of lungs.

After pedagogic experiment in main group (in comparison with control one) confidently $(\mathrm{p}<0.01$ and $\mathrm{p}<0.05$ ) improved indicators of functional condition: vital capacity of lungs, dynamic spirometry, functional tests of Shtange and Genchi, index of will. Also heart beats rate (in rest) indicators and systolic BP confidently improved.

As on the moment of finalizing testing, in experimental group the quantity of students with satisfactory indicators were much higher. At the same time, in control group there was higher quantity of unsatisfactory indicators.

After pedagogic experiment in experimental group, in comparison with control one, quantity of students with critical level of somatic health shortened. With it, by finalizing testing, in experimental group quantity of students with 
moderate level of somatic health was the highest $-52.6 \%$. In control group $52.6 \%$ of students had health below middle level and $26.3 \%$ - at low level. The received results are given in fig.6.

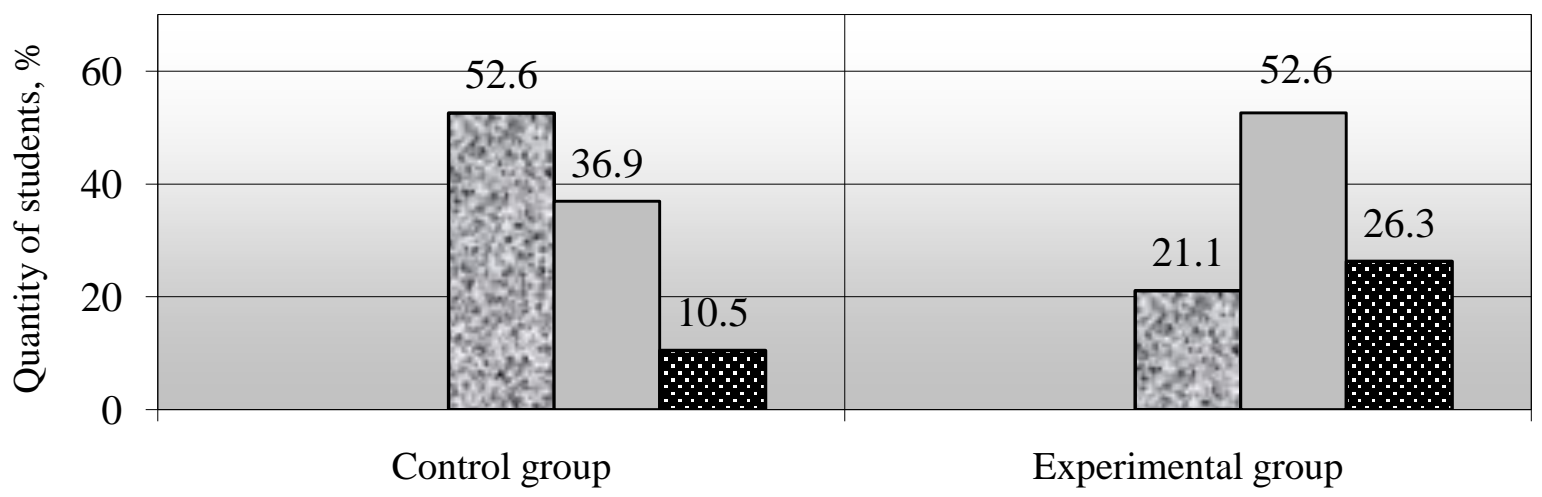

Control group Experimental group

Fig.5. Distribution of control and experimental groups'students in compliance with levels of somatic health, $n=38)$ :

$\therefore$ - high; $Z$ above middle; $\$$-middle; $\square$ - below middle; - low

\section{Conclusions:}

Results of pedagogic observation and conducted questioning witness: students prefer most of all certain kinds of motor functioning. Among offered kinds of sports smoking students preferred the following: outdoor games (boys$36.8 \%$; girls $-28.7 \%$ ); athletic gymnastic (boys $-19.8 \%$; girls $-15.6 \%$ ). The least attractive turned out to be: bicycle sport, non-traditional kinds of sports, gymnastic and chess. That is why, considering motivation of students to certain kinds of sports we organized appropriate forms of trainings.

Results of our research permitted for us to state unsatisfactory functional condition of $1^{\text {st }}-2^{\text {nd }}$ year students, who have harmful habits. After pedagogical experiment in main group, in comparison with control one, confidently ( $p<0.01$ and $\mathrm{p}<0.05$ ) improved indicators of functional condition of organism: VCL, dynamic spirometry, functional tests of Shtange and Genchi, index of will effort, HBR in rest and systolic BP. As on the moment of finalizing testing, in experimental group the quantity of students with satisfactory indicators were much higher. At the same time, in control group there was higher quantity of unsatisfactory indicators.

After pedagogic experiment in experimental group, in comparison with control one, quantity of students with critical level of somatic health shortened. With it, by finalizing testing, in experimental group quantity of students with moderate level of somatic health was the highest $-52.6 \%$. In control group $52.6 \%$ of students had health below middle level and $26.3 \%$ - at low level.

Conflict of interests

The author declares absence of any conflict of interests. 


\section{Reference:}

1 Andreeva T. I., Krasovskij K. S. Tabak $i$ zdorov'e [Tobacco and smoking], Kiev, Polygraph Center TAT, 2004, 224 p. (in Russian)

2 Apanasenko G. L. Kniga o zdorov'e [Book about health], Kiev, Med book, 2007, 132 p. (in Russian)

3 Bernshtejn L. M. Endokrinologiia kureniia [Endocrinology of smoking] Sankt Petersburg, Science, 1997, 127 p. (in Russian)

4 Meshcheriakov B. G., Zinchenko V. P. Bol'shoj psikhologicheskij slovar' [Big psychological dictionary], Sankt Petersburg, Praim, EURO SIGN, 2005, 672 p. (in Russian)

5 Bondarchuk O. I. Psikhologiia deviantnoi povedinki [Psychology of deviant behavior], , MAUP, 2006,88 p. (in Ukrainian)

6 Bogdanova I. M. Social'na pedagogika [Social pedagogic], Kiev, Knowledge, 2008, pp. 53 - 64 . (in Ukrainian)

7 Bulatova M. M. Zdorov'ia i fizichna pidgotovlenist' naselennia Ukraini [Health and physical fitness of Ukrainian population], Teoriia $i$ metodika fizichnogo fikhovannia $i$ sportu, 2004, vol.1, pp. 3 - 8. (in Ukrainian)

8 Gogoleva A. V. Addiktivnoe povedenie i ego profilaktika [Addictive behavior and its prophylaxis], Moscow, NGOs MODEK, 2003, 240 p. (in Russian)

9 Griban V. G. Valeologiia [Valueology], Kiev, 2011, pp. 5 - 7. (in Ukrainian)

10 Zalygina N. A., Obukhov Ia.L., Polikarpov V.A. Addiktivnoe povedenie molodezhi: profilaktika $i$ psikhoterapiia zavisimostej [Addictive behavior of youth: prophylaxis and psycho-therapy of addictions], Minsk, Propylaeum, 2004, 196 p. (in Russian)

11 Zemcova V. I. Osnovni tendencii v dinamici stanu zdorov'ia naselennia Ukraini : neobkhidnist' novoi strategii [Main trends in dynamic of health of Ukrainian population; demand in new strategy]. Teoriia $i$ metodika fizichnogo vikhovannia i sportu, 2006, vol.4, pp. 12 - 15. (in Ukrainian)

12 Korol'chuk I. S., Kolesnikov V.V., Golubcova G.A., Gavrilova L.P. Eksperimental'noe obosnovanie vreda tabakokureniia sredi studentov [Experimental substantiation of tobacco smoking harm among students], Sankt Petersburg, 1998, 103 p. (in Russian)

13 Maksimova N. Iu. Psikhologiia adiktivnoi povedinki [Psychology of addictive behavior], Kiev, 2002, pp. 5 22). (in Ukrainian)

14 Mendelevich V. D. Psikhologiia deviantnogo povedeniia [Psychology of deviant behavior], Moscow, Speech, 2008, 445 p. (in Russian)

15 Pal'chevs'kij S. S. Social'na pedagogika [Social pedagogic], Kiev, Condor, 2009, pp. 376 - 403. (in Ukrainian)

16 Pidpomoga A. Iu., Kravchenko L. S., Zemcov J. F. Virishennia problemi adiktivnoi povedinki students'koi molodi zasobami fizichnoi kul'turi [solution of problem of students' addictive behavior by means of physical culture]. Materiali I Vseukrains'koi naukovo-praktichnoi konferencii [Materials of I All-Ukrainian scientificpractical conference], Kharkiv, 2011, pp. 29 - 32. (in Ukrainian)

17 Pidpomoga A. Iu., Zemcova V. J. Vpliv organizovanoi rukhovoi aktivnosti na funkcional'ni pokazniki studentiv iaki maiut' shkidlivi zvichki [Influence of organized motor functioning on students', having harmful habits, functional indicators]. Sportivnij visnik Pridniprov'ia, 2014, vol.2, pp. 132 - 136. (in Ukrainian)

18 Pidpomoga A. Iu., Zemcova V. J. Profilaktika shkidlivikh zvichok u studentiv zasobami organizovanoi rukhovoi aktivnosti [Prophylaxis of harmful habits among studens by means of organized motor functioning]. Fizichna kul'tura, sport ta zdorov'ia nacii, 2014, vol.1, pp. 223 - 229. (in Ukrainian)

19 Dvoreckaia Liliia. Chto ubivaet Ukrainu. Glavnye prichiny smertnosti ukraincev - kurenie $i$ alkogol' [What kills Ukraine? Main reasons of Ukrainians' mortality - smoking and alcohol]. NBN, Available at: http://nbnews.com.ua/ru/tema/99063 (accessed 10.09.2013) (in Russian)

20 Tvigg D., Uejn Merri I. Nastoiashchij krizis v Ukraine - demograficheskij [Actual crisis in Ukraine demographic]. at: http://economics.lb.ua/state/2014/12/22/290148_nastoyashchiy_krizis_ukraine_.html (accessed 22.12.2014) (in Russian) 


\section{Information about the author:}

Pidpomoga A.Y.: http://orcid.org/0000-0001-8034-0512; Shacti_a@ ukr.net; National University of Physical Education and Sport of Ukraine; Fizkultury str. 1, Kiev, 03680, Ukraine.

Cite this article as: Pidpomoga A.Y. Dynamic of functiona indicators' changes of students having harmful habits (on example of smoking) under influence of organized motion functioning. Physical education of students, 2015, no.2, pp. 22-28. http://dx.doi org/10.15561/20755279.2015.0204

The electronic version of this article is the complete one and can be found online at: http://www.sportpedu.org.ua/html/arhive-e.html

This is an Open Access article distributed under the terms of the Creative Commons Attribution License, which permits unrestricted use, distribution, and reproduction in any medium, provided the original work is properly cited (http:/ creativecommons.org/licenses/by/3.0/deed.en).

Received: 10.04 .2015

Accepted: 25.04.2015; Published: 30.04.2015 